\title{
Analysis of fundamental physical factors influencing channel bank erosion: results for contrasting catchments in England and Wales
}

\author{
V. J. J. Janes ${ }^{1,2}$ (]) A. P. Nicholas ${ }^{1}$ - A. L. Collins ${ }^{3}$ T. A. Quine $^{1}$
}

Received: 9 March 2016/Accepted: 24 March 2017/Published online: 12 April 2017

(c) The Author(s) 2017. This article is an open access publication

\begin{abstract}
Channel bank erosion processes are controlled by numerous factors and as such are both temporally and spatially variable. The significance of channel bank erosion to the sediment budget is difficult to quantify without extensive fieldwork/data analysis. In this study, the importance of key physical factors controlling channel bank erosion, including channel slope, upstream catchment area, channel confinement, and sinuosity, was explored using regression analysis. The resulting analysis can be used in practical studies to provide a first approximation of bank erosion rates (in catchments similar to those investigated). A data set of channel bank erosion rates covering eight contrasting river catchments across England and Wales, over a time period of up to 150 years, was created using a modified GIS methodology. The best predictors were found to be upstream area, channel confinement, and sinuosity with respect to dimensionless width-averaged retreat rates $\left(\mathrm{m} \mathrm{m}^{-1} \mathrm{yr}^{-1}\right)$. Notwithstanding these relationships, the results highlight the variability of the magnitude of sediment production by channel bank erosion both within and between catchments.
\end{abstract}

Keywords Channel bank erosion · Sediment - Channel confinement $\cdot$ Sinuosity

V. J. J. Janes

v.janes@lancaster.ac.uk

1 Department of Geography, University of Exeter, Exeter EX4 4RG, UK

2 Lancaster Environment Centre, University of Lancaster, Lancaster LA1 4YQ, UK

3 Sustainable Soils and Grassland Systems Department, Rothamsted Research, North Wyke, Okehampton EX20 2SB, UK

\section{Introduction}

Channel bank erosion processes are a source of sediment within river catchments and have been shown to represent a significant component of the catchment sediment budget (Collins et al. 1997; Owens et al. 2000; Wilkinson et al. 2005; De Rose et al. 2005; Walling and Collins 2005; Walling 2005; Walling et al. 1999, 2008; Collins et al. 2012; Kronvang et al. 2013; Lu et al. 2015; Neal and Andera 2015). Bank erosion may entrain fine-grained sediment with high loading of pollutants (e.g. nutrients including phosphorus and heavy metals). Additionally, enhanced sediment mobilisation and delivery can result in detrimental biological and ecological impacts in river systems such as a reduction in biodiversity (e.g. decreased salmon spawning success as observed by Theurer et al. 1998 and Soulsby et al. 2001), and lowering of productivity due to a reduction in the depth of the photic zone (Devlin et al. 2008). The EU Water Framework Directive (WFD) requires Member States to achieve chemical and ecological standards for rivers, and these are strongly influenced by fine sediment mobilisation and transport. Therefore, whilst explicit sediment thresholds are not defined in the WFD, there is growing recognition of the need for improved understanding of sediment generation mechanisms for supporting the development of river basin management plans aimed at controlling diffuse pollution problems (Collins et al. 2011).

Rates of channel bank erosion are influenced by numerous factors such as the composition of bank material (Hooke 1980; Bull 1997; Couper 2003; Julian and Torres 2006), bank geometry (Micheli and Kirchner 2002; Laubel et al. 2003; Walling 2005; Walling et al. 2006), discharge magnitude (Knighton 1973; Gautier et al. 2007; Hooke 2008), and riparian vegetation (Micheli and Kirchner 2002; 
Simon and Collison 2002; Laubel et al. 2003; Mattia et al. 2005). The effects of anthropogenic factors include, amongst others, removal of bank vegetation increasing bank erosion (Allan et al. 1997), trampling and poaching by livestock (Kondolf et al. 2002; Collins et al. 2013), the influence of flood control structures reducing peak flows (Michalková et al. 2011), and increased bank erosion in urban areas due to flashier run-off (Neller 1988). As such, bank erosion rates are highly spatially and temporally variable (Hooke 1980; Bull 1997; Lawler et al. 1999; Leys and Werritty 1999; Couper et al. 2002; Collins and Anthony 2008; Collins et al. 2009a, b).

The influence of channel radius of curvature on bank erosion rates has been noted in several studies (Hickin and Nanson 1975; Thorne 1991; Hooke 2003) as a result of changes to flow geometry within the channel with changes in curvature. As radius of curvature decreases, high velocity flow is directed towards the outer channel bank, increasing bank erosion rates. Below a threshold value, bank erosion rates decline with further lowering of radius of curvature due to the formation of secondary cells, protecting the bank (Hey and Thorne 1975; Bathurst et al. 1977). Knighton (1998) also noted the change in shear stress distribution within channels of low radius of curvature resulting in accelerated downstream migration. This is due to the point of maximum flow velocity (and hence maximum shear stress) being located downstream of the bend apex in highly sinuous channels. Channel curvature (and curvature ratio; radius of curvature divided by channel width) is inversely related to sinuosity up to sinuosities of approximately 1.5; above this value, channel curvature ratio decreases with increasing sinuosity (Julien 2002). A relationship between bank erosion and channel sinuosity has also been noted (Abam 1993; Schilling and Wolter 1999).

Channel bank erosion (and therefore lateral migration) may also be restricted by valley walls. Lewin and Brindle (1977) first identified channel confinement and described three degrees of confinement based on decreasing valley width relative to channel width: (1) wide-floored valleys with infrequent contact with valley walls, (2) floodplains narrower than the amplitude of meander bends, and (3) well-developed meandering restricting further meander development. Links between channel sinuosity and confinement have been observed; lower values of sinuosity are found within confined sections of river channel (Milne 1983; Tooth et al. 2002; Nicoll and Hickin 2010). However, little has been done to investigate the influence of confinement on channel bank erosion rates.

Previous empirical studies have observed bank erosion rates over timescales of months to years using a range of field techniques (Collins and Walling 2004) such as erosion pin monitoring (Lawler 1993; Ashbridge 1995), repeated cross-channel surveys (Hickin and Nanson 1975), and aerial photographs (Hooke 1980; Micheli and Kirchner 2002). Photo-electronic erosion pin (PEEP) monitoring (Lawler 1991) is based on a development of standard erosion pin measurements and provides information regarding the temporal variability of bank erosion during the monitoring period (Bull 1997; Lawler et al. 1997). Consecutive cross-channel surveys provide a measurement of total channel bank erosion and deposition (Lawler 1993; Julian and Torres 2006). Although labour-intensive, these methodologies are capable of quantifying bank erosion over relatively small spatial scales (channel reaches of a few kilometres, to single channels). Aerial photogrammetry (Kondolf et al. 2002; Michalková et al. 2011) in conjunction with LIDAR data (De Rose and Basher 2011) has also been used to observe planimetric changes. However, these methods are limited by the availability and temporal coverage of both photogrammetric and LIDAR data.

Against this context, predictive models are required to help estimate river bank erosion rates over large spatial scales and representative and meaningful time periods. This paper aims to (1) provide a data set of observed channel bank erosion rates for several contrasting catchments across England and Wales and timescales of up to 150 years, (2) establish the significance of key physical controls on bank erosion rates including slope, sinuosity, upstream catchment area, and channel confinement for developing simple predictive tools. The control variables selected for analysis within this study can be efficiently calculated across river catchments, and corresponding input parameter values can be incorporated within catchment scale sediment models. It is thus envisaged that the findings from this study will provide a basis for further development of simple bank erosion modelling tools and a data set to validate such models over long timescales.

\section{Methods}

A GIS methodology, similar to 'polygon overlay', as reported by Gurnell et al. (1994) was used within this study covering seven catchments (65 WFD cycle 1 sub-catchment) from England and Wales. River channels were digitised using historical Ordnance Survey (OS) maps (for scales, see Table 2), thereby allowing observation of channel migration over a period of up to 150 years. The desktop data collection and analysis were conducted on the 65 sub-catchments located within the seven study catchments (Fig. 1); Avon (Hampshire), Exe (Devon), Test and Itchen (Hampshire), Stour (Kent), Ouse (Yorkshire), Eye (Leicestershire), and Wye (Herefordshire). The main channels and tributaries within each of these catchments were digitised (Table 1). The study catchments were 


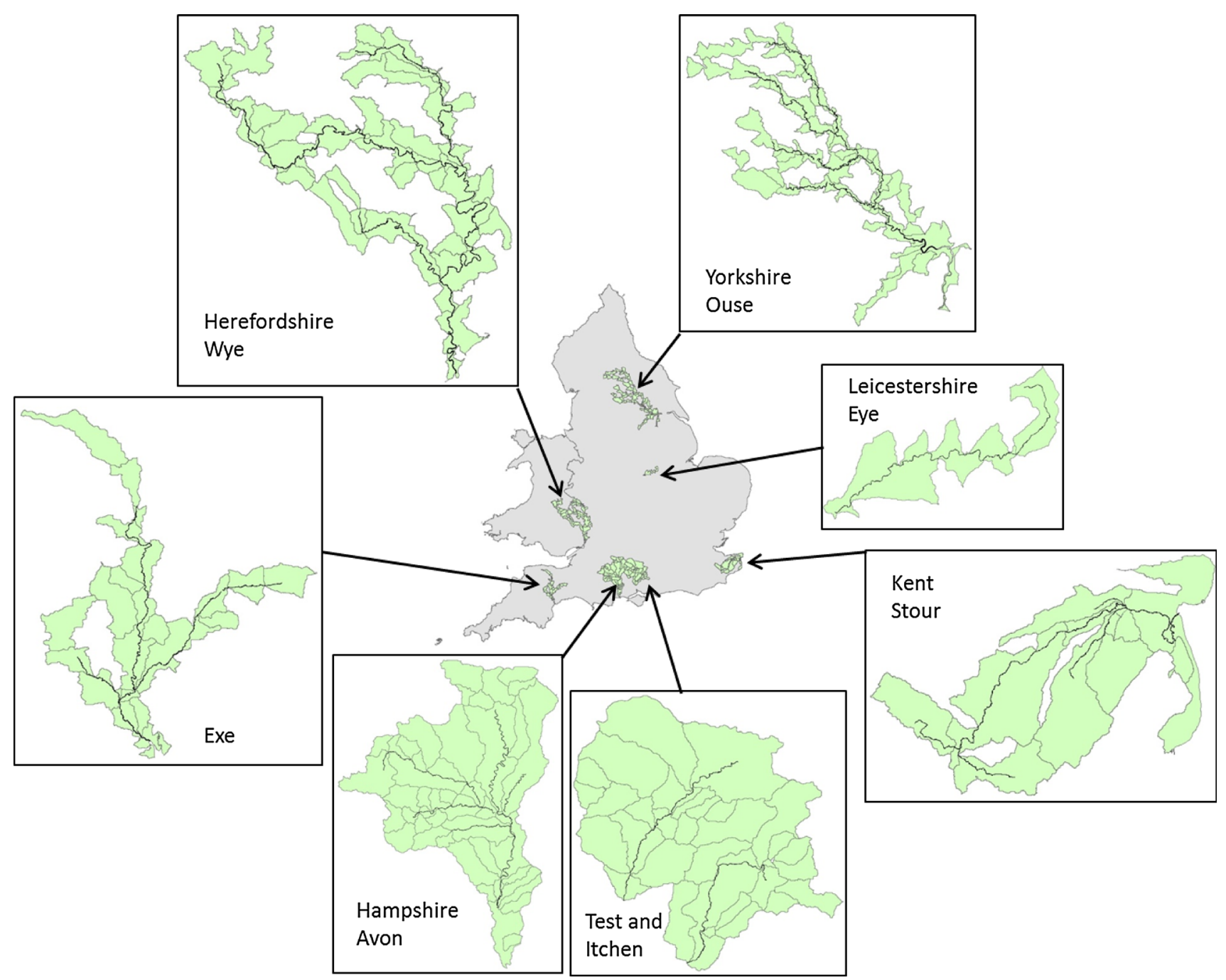

Fig. 1 Location of the study catchments. The channels digitised and WFD sub-catchments are also shown

selected to represent a range of different catchment types (i.e. underlying geologies, channel characteristics, and land use) and to cover the range of annual precipitation totals across England and Wales since rainfall/run-off has identified as a key driver for channel bank erosion (Collins and Anthony 2008). See Table 1 for further details. Collectively, the study catchments are more representative of permeable than impermeable geologies and associated soils and of rural areas dominated by different types of mixed farming. This should be considered in terms of the scope for extrapolation.

Historical Ordnance Survey maps were downloaded for various years (taken from different mapping series, see Table 2) for each of the study catchments. As the dates and coverage varies between mapping series, the corresponding dates of maps varied between the study catchments (Table 1). Neighbouring maps within the same map edition also have different survey and revision dates. Therefore, an estimate of the date of one map layer was taken from the range of years of map creation (often up to 15 years).

Channel bank lines at each time period were manually digitised and the corresponding polygons created. Channel polygons of 2 consecutive time periods were overlain (i.e. 1890-1940, 1940-1970, 1970-2010) providing an area of channel erosion between these two time periods (as per Table 3). It was noted that this method of erosion calculation would underestimate bank erosion in any areas where the channel had migrated to a degree that the polygons from the two time periods represented did not overlap (and no channel is present at either time period, see Fig. 2). In such cases, an 'erosion island' would be omitted from the estimation. Consequently, each overlay was examined individually for areas where channel migration between the time periods of the two digitised channels was sufficient to result in a gap between the positioning of both channels. These gaps were digitised and their area added to 
Table 1 Study catchments and channels digitised, and corresponding dates of OS map data

\begin{tabular}{|c|c|c|c|c|c|c|c|}
\hline Catchment & $\begin{array}{l}\text { Drainage } \\
\text { area }\left(\mathrm{km}^{2}\right)\end{array}$ & $\begin{array}{l}\text { Annual } \\
\text { precipitation } \\
(\mathrm{mm} / \mathrm{pa})\end{array}$ & Land use & $\begin{array}{l}\text { Average } \\
\text { channel } \\
\text { slope }\end{array}$ & Geology & $\begin{array}{l}\text { Channels } \\
\text { digitised }\end{array}$ & Map years \\
\hline Exe & 1500 & $800-2300$ & Predominately rural—grazing & 0.004 & $\begin{array}{l}\text { Sandstone } \\
\text { and } \\
\text { mudstones }\end{array}$ & $\begin{array}{l}\text { Exe } \\
\text { Culm } \\
\text { Creedy }\end{array}$ & $\begin{array}{l}1890,1962 \\
1970,2010\end{array}$ \\
\hline Avon & 1750 & $833->1000$ & $\begin{array}{l}98 \% \text { rural—arable, improved } \\
\text { pasture grasslands and woodlands }\end{array}$ & 0.002 & Chalk & $\begin{array}{l}\text { Avon } \\
\text { Bourne } \\
\text { Ebble } \\
\text { Nadder } \\
\text { Wylye }\end{array}$ & $\begin{array}{l}1890,1926, \\
1985,2010\end{array}$ \\
\hline Ouse & 4847 & $600-1700$ & $95 \%$ agriculture & 0.002 & $\begin{array}{l}\text { Limestone } \\
\text { and } \\
\text { sandstone }\end{array}$ & $\begin{array}{l}\text { Ouse/Ure } \\
\text { Swale } \\
\text { Nidd } \\
\text { Wharfe }\end{array}$ & $\begin{array}{l}1860,1940, \\
1975,2010\end{array}$ \\
\hline $\begin{array}{l}\text { Test } \\
\text { Itchen }\end{array}$ & 1760 & $800-1000$ & Predominately arable and pasture & 0.002 & Chalk & $\begin{array}{l}\text { Test } \\
\text { Itchen }\end{array}$ & $\begin{array}{l}1875,1940, \\
1985,2010\end{array}$ \\
\hline Wye & 4100 & $744->2500$ & $\begin{array}{l}96 \% \text { rural, predominately } \\
\text { agriculture }\end{array}$ & 0.008 & Sandstones & $\begin{array}{l}\text { Wye } \\
\text { Monnow } \\
\text { Lugg }\end{array}$ & $\begin{array}{l}1890,1975 \\
2010\end{array}$ \\
\hline Stour & 1200 & $600-850$ & $83 \%$ agriculture & 0.005 & Chalk & $\begin{array}{l}\text { Stour } \\
\text { East Stour } \\
\text { Little } \\
\text { Stour } \\
\text { Sarre } \\
\text { Penn }\end{array}$ & $\begin{array}{l}1875,1940 \\
1985,2010\end{array}$ \\
\hline Eye & 339 & 642 & Rural, predominately agriculture & 0.001 & Sandstone & Eye & $\begin{array}{l}1890,1950 \\
1983,2010\end{array}$ \\
\hline
\end{tabular}

the erosion area calculated for the corresponding subcatchment from the overlay process. However, it was also noted that this methodology would overestimate bank erosion where channel movement has occurred by cut-off rather than lateral migration. As erosion island digitisation was conducted manually, channel cut-offs were not included (see Fig. 2).

The polygon overlay and 'erosion island' method was used to calculate a total area of bank erosion $\left(\mathrm{m}^{2}\right)$ within each of the digitised 65 sub-catchments comprising the seven study catchments. This was converted into a lateral retreat rate $(\mathrm{m})$ and a corresponding yield of sediment $\left(\mathrm{kg} \mathrm{yr}^{-1}\right)$. Retreat rates were calculated by dividing the erosion area polygon of each sub-catchment by the length of the channel network therein. This was converted into an annual retreat rate $\left(\mathrm{m} \mathrm{yr}^{-1}\right)$ by dividing by the number of years covered by the time period between maps, and a width-averaged retreat rate $\left(\mathrm{m} \mathrm{m}^{-1} \mathrm{yr}^{-1}\right)$ by dividing by the average river channel width.

To convert the area of bank erosion to a mass of sediment, values of bulk density and bank height were required (to estimate a volume of bank-eroded sediment; $\mathrm{m}^{3}$ ).
Estimates of river bank height from 175 locations across the 65 sub-catchments were taken from the UK River Habitat Survey database (RHS, Environment Agency 2008). As RHS survey points are located randomly within individual WFD sub-catchments, the values of bank height within any individual sub-catchment were averaged to produce a spatially averaged estimate. As bank heights may vary considerably within individual sub-catchments (see Table 4), this method of bank height estimation will inevitably introduce errors. Although bank height may influence bank erosion rates (through changes to shear stress acting on the bank face), the influence of this factor was not considered within this study due to the errors associated with the estimation of this variable. Sediment volume was then converted to a corresponding mass by multiplying by bulk sediment density (Table 4). An average sediment bulk density was estimated for each of the 65 sub-catchments using LandIS (2014) soil association data. As in the estimation of bank height, the estimation of sediment bulk density using this method is associated with unavoidable uncertainty. 
Table 2 Historical mapping series, and scales used for each time period digitised

\begin{tabular}{|c|c|c|c|c|c|c|c|c|}
\hline \multirow[t]{3}{*}{ Catchment } & \multicolumn{8}{|c|}{ Historical maps } \\
\hline & \multicolumn{2}{|c|}{ Time period 1} & \multicolumn{2}{|c|}{ Time period 2} & \multicolumn{2}{|c|}{ Time period 3} & \multicolumn{2}{|c|}{ Time period 4} \\
\hline & Year & $\begin{array}{l}\text { Map series and } \\
\text { scale }\end{array}$ & Year & Map series and scale & Year & Map series and scale & Year & $\begin{array}{l}\text { Map series and } \\
\text { scale }\end{array}$ \\
\hline Exe & 1890 & $\begin{array}{l}\text { County Series } \\
1: 2500\end{array}$ & 1962 & National Grid 1:10560 & 1970 & National Grid 1:2500 & 2010 & $\begin{array}{l}\text { Mastermap } \\
1: 2500\end{array}$ \\
\hline Avon & 1890 & $\begin{array}{l}\text { County Series } \\
1: 2500\end{array}$ & 1926 & $\begin{array}{l}\text { County Series 2nd revision } \\
1: 10560\end{array}$ & 1985 & $\begin{array}{l}\text { National Grid (latest) } \\
1: 10000\end{array}$ & 2010 & $\begin{array}{l}\text { Mastermap } \\
1: 2500\end{array}$ \\
\hline Ouse & 1890 & $\begin{array}{l}\text { County Series } \\
1: 10560\end{array}$ & 1940 & $\begin{array}{l}\text { County Series 3rd revision } \\
1: 10560\end{array}$ & 1975 & National Grid 1:2500 & 2010 & $\begin{array}{l}\text { Mastermap } \\
1: 2500\end{array}$ \\
\hline $\begin{array}{l}\text { Test and } \\
\text { Itchen }\end{array}$ & 1875 & $\begin{array}{l}\text { County Series } \\
1: 10560\end{array}$ & 1940 & $\begin{array}{l}\text { County Series 3rd revision } \\
\text { 1:10560 }\end{array}$ & 1985 & $\begin{array}{l}\text { National Grid (latest) } \\
1: 10000\end{array}$ & 2010 & $\begin{array}{l}\text { Mastermap } \\
1: 2500\end{array}$ \\
\hline Wye & 1890 & $\begin{array}{l}\text { County Series } \\
1: 10560\end{array}$ & No da & & 1975 & National Grid 1:2500 & 2010 & $\begin{array}{l}\text { Mastermap } \\
1: 2500\end{array}$ \\
\hline Stour & 1875 & $\begin{array}{l}\text { County Series } \\
1: 10560\end{array}$ & 1950 & $\begin{array}{l}\text { County Series 3rd revision } \\
1: 10560\end{array}$ & 1983 & $\begin{array}{l}\text { National Grid (latest) } \\
1: 10000\end{array}$ & 2010 & $\begin{array}{l}\text { Mastermap } \\
1: 2500\end{array}$ \\
\hline Eye & 1890 & $\begin{array}{l}\text { County Series } \\
1: 10560\end{array}$ & 1950 & $\begin{array}{l}\text { County Series 3rd revision } \\
1: 10560\end{array}$ & 1983 & $\begin{array}{l}\text { National Grid (latest) } \\
1: 10000\end{array}$ & 2010 & $\begin{array}{l}\text { Mastermap } \\
1: 2500\end{array}$ \\
\hline
\end{tabular}

Table 3 Simple polygon overlay analysis method used to estimate bank erosion

\begin{tabular}{llll}
\hline & & Year 1 & \\
\cline { 3 - 4 } & & Channel & No channel \\
\hline Year 2 & Channel & No change & Erosion \\
& No channel & Deposition & No change \\
\hline
\end{tabular}

Potential sources of error within the GIS 'erosion island' overlay methodology include inaccuracies within the georeferencing of historical Ordnance Survey maps. Downward et al. (1994) outlined a methodology where ground control points (GCPs) are used to quantify the error associated with the geo-rectification processes. Previous studies have illustrated the use of buffers around digitised channels to ensure the magnitude of measured channel change using the overlay methodology is greater than the mapping error; RMSE of geo-rectifying errors is used to inform the magnitude of buffers (cf. Hughes et al. 2006-5 m buffer; Rhoades et al. 2009-2 m buffer). Therefore, as geo-referencing of historical OS maps has been completed prior to download, a similar buffer methodology was used to account for potential geo-referencing errors. Channel overlays and erosion estimation were carried out in two ways: (1) using no buffers and (2) with a $3.5 \mathrm{~m}$ buffer (median value from the existing literature) applied to the older channel within the overlay. With the buffer applied, any channel migration less than $3.5 \mathrm{~m}$ during the overlay time period was not included within the estimation of bank erosion. This method therefore provides a minimum estimate of channel bank erosion. Additionally, the digitised channel overlays were checked manually for geo-referencing errors and any obvious problems.

For each WFD sub-catchment $(n=65)$ and for each time overlay (of which there were up to three, depending on data availability), bank erosion rate was calculated as a yield $\left(\mathrm{kg} \mathrm{ha}^{-1} \mathrm{yr}^{-1}\right)$ and a width-averaged retreat rate $\left(\mathrm{m} \mathrm{m}^{-1} \mathrm{yr}^{-1}\right)$ both with and without a buffer applied to produce a lower and upper estimate of each. Time periods of channel overlays may coincide with flood-rich/floodpoor years, or particular high-magnitude geomorphic events. As this study sought to investigate the influence of physical characteristics on channel bank erosion rates, as opposed to the specific influence of high flows, bank erosion rates across all time periods were averaged for each study sub-catchment.

\section{Estimation of variables potentially controlling river bank erosion}

The potential controlling variables, such as upstream catchment area, slope, sinuosity, and channel confinement, were measured within each study sub-catchment using GIS. Upstream catchment area was calculated by summing the area of upstream sub-catchments using GIS shapefiles (provided by the Environment Agency). Slope was measured using OS contours (at 5-m intervals) with a single value of slope calculated for each sub-catchment. In some catchments, the value of slope was 0 ( 6 of 65 sub-catchments). In 
Fig. 2 a Yorkshire Ouse catchment and digitised channels. Square shows location of $\mathbf{b}$. b Section of the River Swale sub-catchment illustrating the overlay island inclusion methodology. Flow is from top to bottom. Grey channel: 1940, Blue channel: 1975, White: Channel presents both in 1940 and 1975, Dark blue sections: 'erosion islands'. Arrows indicate flow direction

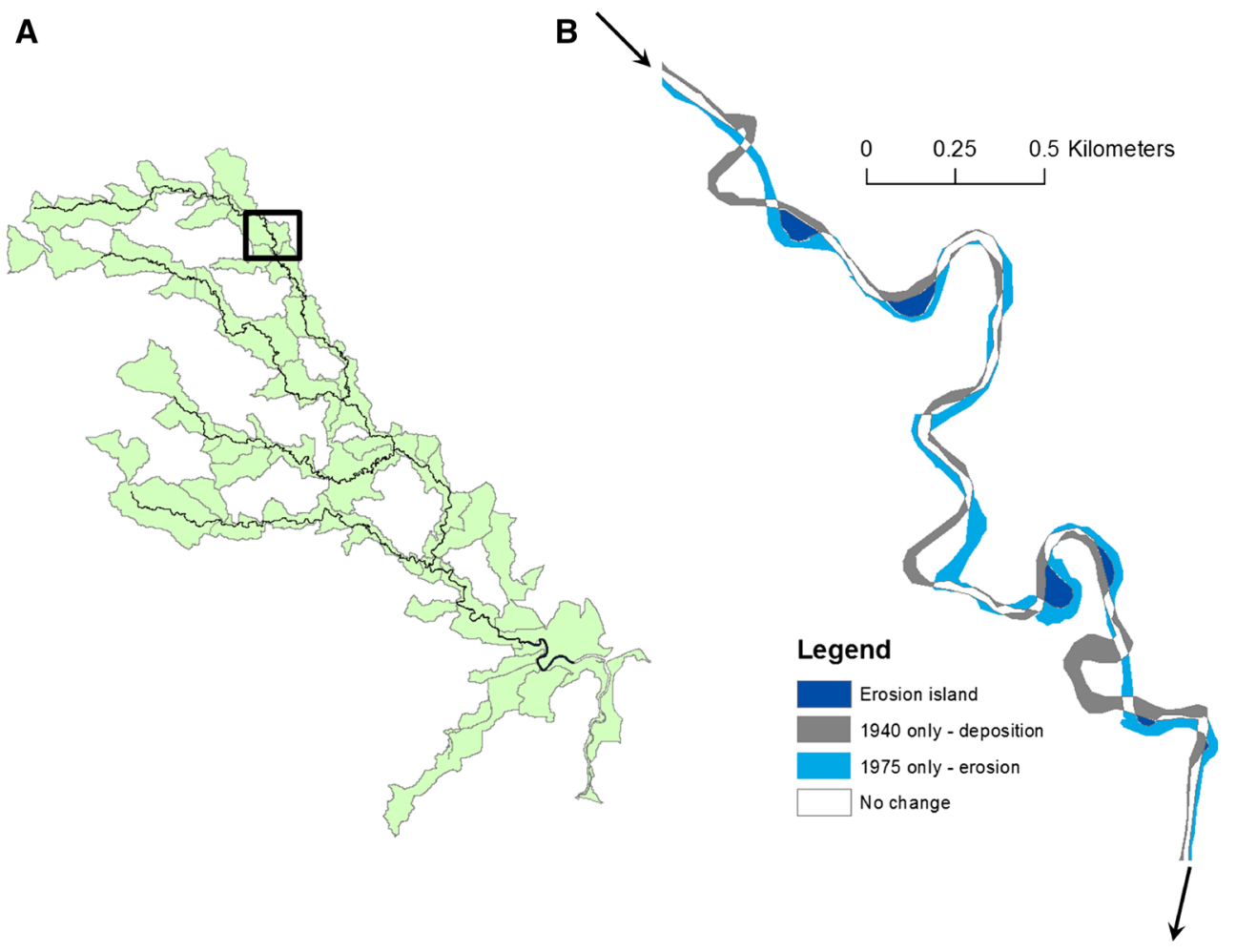

Table 4 Statistics of bank height data and values of sediment bulk densities for each catchment

\begin{tabular}{lllll}
\hline & $\begin{array}{l}\text { Minimum } \\
\text { bank height } \\
(\mathrm{m})\end{array}$ & $\begin{array}{l}\text { Maximum } \\
\text { bank height } \\
(\mathrm{m})\end{array}$ & $\begin{array}{l}\text { Average } \\
\text { bank height } \\
(\mathrm{m})\end{array}$ & $\begin{array}{l}\text { Sediment bulk } \\
\text { density } \\
\left(\mathrm{kg} \mathrm{m}^{-3}\right)\end{array}$ \\
\hline Exe & 0.2 & 3.4 & 1.6 & 1243 \\
Avon & 0.1 & 2 & 0.9 & 1252 \\
Ouse & 0.1 & 6 & 2.3 & 1300 \\
Test & 0.2 & 1.4 & 0.6 & 1016 \\
and & & & & \\
Itchen & & & 2.6 & 1314 \\
Wye & 0.5 & 6 & 1.3 & 1328 \\
Stour & 0.3 & 3 & 0.6 & 1234 \\
Eye & 0.2 & 2.2 &
\end{tabular}

Sediment bulk density values indicate the average bulk density within each catchment

these catchments, the resolution of the elevation data resulted in no observable slope. The use of higher resolution topography data (Lidar data-2-m resolution) was not feasible due to the large spatial coverage of data collection $\left(>15,000 \mathrm{~km}^{2}\right)$. Furthermore, the resolution of topographic data used is similar to or greater than that used in estimates of sediment generation at the catchment scale (Biswas and Pani 2015-30 m; Hessel and van Asch 2003-5 m; Lu et al. 2004-30 m; Vente et al. 2008-100 m). Sinuosity was measured at 750-m intervals along the channel centreline and then averaged to provide one value of sinuosity for each channel per sub-catchment. This measurement length was chosen as it was found to represent the average length of multiband loops across the study catchments (see Janes 2013). The degree of channel confinement within a valley can be expressed in several different ways and, as a result, three different methods were used to estimate channel confinement and its relationship with bank erosion rates. The three methods included were as follows:

1. Confinement ratio based on the channel width, calculated as the floodplain width divided by the bankfull channel width (Rapp and Abbe 2003; Hall et al. 2007). Hall et al. (2007) reported that confined channels had a ratio of $\leq 3.8$ and unconfined channels $>3.8$.

2. Confinement ratio based on meander belt width version A. From field observations, Mackey and Bridge (1992) observed a relationship $(R=0.94)$ between belt width $(B)$ and channel width $(w)$. This relationship took the form: $B=6.89 . w^{0.99}$

The confinement ratio was then calculated as floodplain width divided by belt width, as estimated from this relationship.

3. Confinement ratio using meander belt width version B, which is slightly modified form of 2 above. Williams (1986) observed a relationship $(R=0.96)$ between belt width $(B)$ and channel width $(w)$ taking the form: $B=4.3 . w^{1.12}$ 
Again, the confinement ratio was calculated as floodplain width divided by belt width as estimated from this empirical relationship.

Channel width was measured using the digitised channels at 5-km intervals within each sub-catchment and an average channel width was calculated on this basis. Floodplain width was measured using shapefiles for the Environment Agency's flood zone 3, representing the inundated floodplain area for an annual flood with $>1 \%$ probability (up to 100 year return period). The floodplain width for each sub-catchment was derived from this area by dividing by the corresponding sub-catchment valley length.

The relationship between channel bank erosion rate $\left(\mathrm{m} \mathrm{m}^{-1} \mathrm{yr}^{-1}\right)$ and the study catchment characteristics (upstream catchment area, slope, sinuosity, and channel confinement) was analysed using Pearson's correlation and regression analysis. The distribution of all input variables was assessed prior to statistical analysis to ensure normality for parametric testing. Normality was assessed by checking similar values of mean, median, and mode, a skewness statistic between +1 and -1 , and kurtosis between +3 and -3 . Non-normally distributed variables were log-transformed. Correlation analysis was used initially to assess relationships between bank erosion rate and each of the independent variables individually. Independent variables were then correlated to ensure no multicollinearity. Multiple regression analysis was performed to investigate the proportion of channel bank erosion that can be explained by the combination of independent variables. Due to uncertainty associated with channel bank height and sediment bulk density estimates, the annual mass of bankeroded sediment $\left(\mathrm{kg} \mathrm{ha}^{-1} \mathrm{yr}^{-1}\right)$ within each catchment was calculated, but not included within the regression analysis.

\section{Results}

Table 5 presents the estimates of mean rates of bank erosion for both overlay methodologies (with and without buffers) calculated for each of the seven study catchments for which data were collated. The results suggest that the highest erosion rate calculated as a yield of sediment $\left(\mathrm{kg} \mathrm{ha}^{-1} \mathrm{yr}^{-1}\right)$ was observed in the River Exe catchment, and the corresponding lowest rate in the Rivers Test and Itchen catchment. The highest annual retreat rates were observed in the River Avon catchment, the largest widthaveraged retreat rate in the River Stour catchment, and the lowest retreat rates were estimated for the River Wye catchment. The data presented here are the average values of all time period overlays for each sub-catchment (Fig. 1). The histograms in Fig. 3 show the variability of estimated channel bank erosion rates between all 65 WFD subcatchments comprising the seven study areas.

The range of estimates of the annual mass of sediment produced by bank erosion calculated for each of the channels digitised within this study (see Table 1) is presented in Table 6. These values are the maximum and minimum estimates from the individual overlay time periods for each channel network (as opposed to the average of all overlay time periods) and are from overlay methodologies with and without buffers applied, respectively. The uncertainty within these estimates is large (as indicated by the magnitude of difference between the upper and lower estimates). This uncertainty is due to both error and uncertainty within the methodology, including error within the mapping process (accounted for by the buffers). Lower estimates are from the overlay methodology with $3.5 \mathrm{~m}$ buffers applied, and upper estimates are from the overlay methodology without buffers. It is possible that inter-annual variability of bank erosion (primarily a result of annual variability in rainfall and resulting river discharge) may also account for some of this uncertainty. As these values are taken from individual overlay time periods (as opposed to the averaged value from the three overlay time periods), variation between upper and lower estimates will increase due to temporal variation of bank erosion rates across the time periods; flood-rich periods would be expected to produce higher rates of bank erosion than flood-poor periods. These values represent the gross yield of sediment released by channel bank erosion, and therefore incorporate bankeroded sediment that will be subsequently re-deposited within the channel network. The range of values shown in Table 6 therefore accounts for error associated with the mapping process but do not account for errors associated with the channel bank height and sediment bulk density estimation. The limitations associated with the accuracy of these data will introduce further uncertainty into these estimates of mass of bank-eroded sediment that has not been accounted for explicitly. The estimates in Table 6 provide a good illustration of the variability of channel bank erosion not only between, but also within, the individual study catchments. Data generated by other studies are presented in Table 7.

All independent variables showed non-normal distributions. Width-averaged retreat rate without buffers was the only normally distributed variable. $\log _{10}$ transformation achieved normal distributions for all independent variables except slope. As the independent variable slope contained some 0 values, a standard $\log _{10}$ transformation alone was unsuitable; therefore, a constant of 0.0001 was added to all values before $\log _{10}$ transformation (similarly to previous studies; Berry 1987; Yamamura 1999). 
Table 5 Mean channel bank erosion rates for each of the study catchments

\begin{tabular}{|c|c|c|c|c|c|c|}
\hline & \multicolumn{3}{|l|}{ No buffer } & \multicolumn{3}{|c|}{ With $3.5 \mathrm{~m}$ buffer } \\
\hline & $\begin{array}{l}\text { Erosion } \\
\left(\mathrm{kg} \mathrm{ha}^{-1} \mathrm{yr}^{-1}\right)\end{array}$ & $\begin{array}{l}\text { Retreat rate } \\
\left(\mathrm{m} \mathrm{yr}^{-1}\right)\end{array}$ & $\begin{array}{l}\text { Width-averaged } \\
\text { retreat } \\
\text { rate }\left(\mathrm{m} \mathrm{m}^{-1} \mathrm{yr}^{-1}\right)\end{array}$ & $\begin{array}{l}\text { Erosion } \\
\left(\mathrm{kg} \mathrm{ha}^{-1} \mathrm{yr}^{-1}\right)\end{array}$ & $\begin{array}{l}\text { Retreat rate } \\
\left(\mathrm{m} \mathrm{yr}^{-1}\right)\end{array}$ & $\begin{array}{l}\text { Width-averaged } \\
\text { retreat } \\
\text { rate }\left(\mathrm{m} \mathrm{m}^{-1} \mathrm{yr}^{-1}\right)\end{array}$ \\
\hline Exe & 907 & 0.114 & 0.0078 & 388 & 0.051 & 0.0035 \\
\hline Avon & 322 & 0.117 & 0.0082 & 298 & 0.129 & 0.0080 \\
\hline $\begin{array}{l}\text { Test and } \\
\text { Itchen }\end{array}$ & 65 & 0.090 & 0.0059 & 32 & 0.047 & 0.0032 \\
\hline Stour & 113 & 0.075 & 0.0091 & 52 & 0.039 & 0.0049 \\
\hline Wye & 732 & 0.074 & 0.0039 & 347 & 0.040 & 0.0023 \\
\hline Eye & 570 & 0.086 & 0.0072 & 302 & 0.046 & 0.0038 \\
\hline Ouse & 701 & 0.105 & 0.0049 & 447 & 0.066 & 0.0030 \\
\hline
\end{tabular}

Lower and upper estimates (with and without $3.5 \mathrm{~m}$ buffer used in overlay methodology) shown

Correlations between each of the independent variables and each dependent variable were then calculated (Table 8). As no statistically significant correlations were observed between retreat rate and any of the independent variables, no further statistical analysis of this dependent variable was conducted. Scatterplots were used to assess linearity of the relationships the remaining dependent variables and all independent variables individually (Fig. 4). The two methods of channel confinement estimation using meander belt ( $\mathrm{CC} 2$ and $\mathrm{CC} 3$ ) width were more normally distributed than methodology 1 ; therefore, these two variables used were chosen for further analysis.

Table 9 shows the correlation matrix for the transformed independent variables. All independent variables entered into a regression model should be independent from each other (i.e. there should be no significant correlations between pairs of independent variables) to avoid statistical redundancy. Variables were assumed independent where the statistical significance of the relationship was less than the $95 \%$ level.

Table 9 indicates that the variables $\mathrm{CC} 2$ and $\mathrm{CC} 3$ are significantly correlated (at the $99 \%$ level) and therefore should not be included in the regression analysis together. This is to be expected as all these variables represent channel confinement, so are characterising the same potential control on bank erosion. On this basis, only one of the channel confinement variables was selected for each regression analysis. Table 9 also indicates a significant relationship between upstream area and sinuosity at the 95\% level and therefore, these two variables were not included within the same final regression models. Additionally, the tolerance statistic (output from the regression models) should be $>0.1$, confirming that multicollinearity is not an issue within the statistical model.
Stepwise regression was used; all independent variables were entered into the initial regression models. Although individual variables may not be statistically significant, when combined with other variables, they may show a significant relationship and enhance the $R$ and $R^{2}$ values associated with the model. The contribution of each variable to the model is shown by the t statistic, and any independent variables that did not show a statistically significant contribution at the $95 \%$ level or above were removed from the final regression model.

\section{Width-averaged retreat}

The variables upstream area and channel confinement showed statistically significant relationships with widthaveraged bank retreat rate (at the $99 \%$ level) both with and without buffers applied. Sinuosity and slope showed weak relationships with width-averaged retreat rate (sinuosity: $R=0.289, R={ }^{*}-0.120$, slope: $R=0.219, R=-0.013$ without and with buffers, respectively).

The regression model was initially run with all 65 data points (i.e. for all WFD sub-catchments comprising the seven study areas). One data point 61 (River Monnow) showed a disproportionate influence on the corresponding regression coefficients; centred leverage value of 0.175 . Centred leverage values indicate the influence of each individual data point on the regression equation, highlighting points with a disproportionate influence. High leverage values can be identified as greater than.

$\frac{2 p}{N}$

where $p$ is the number of independent variables and $N$ is the number of cases. This point has the smallest value of upstream area within the data set, which could partially 

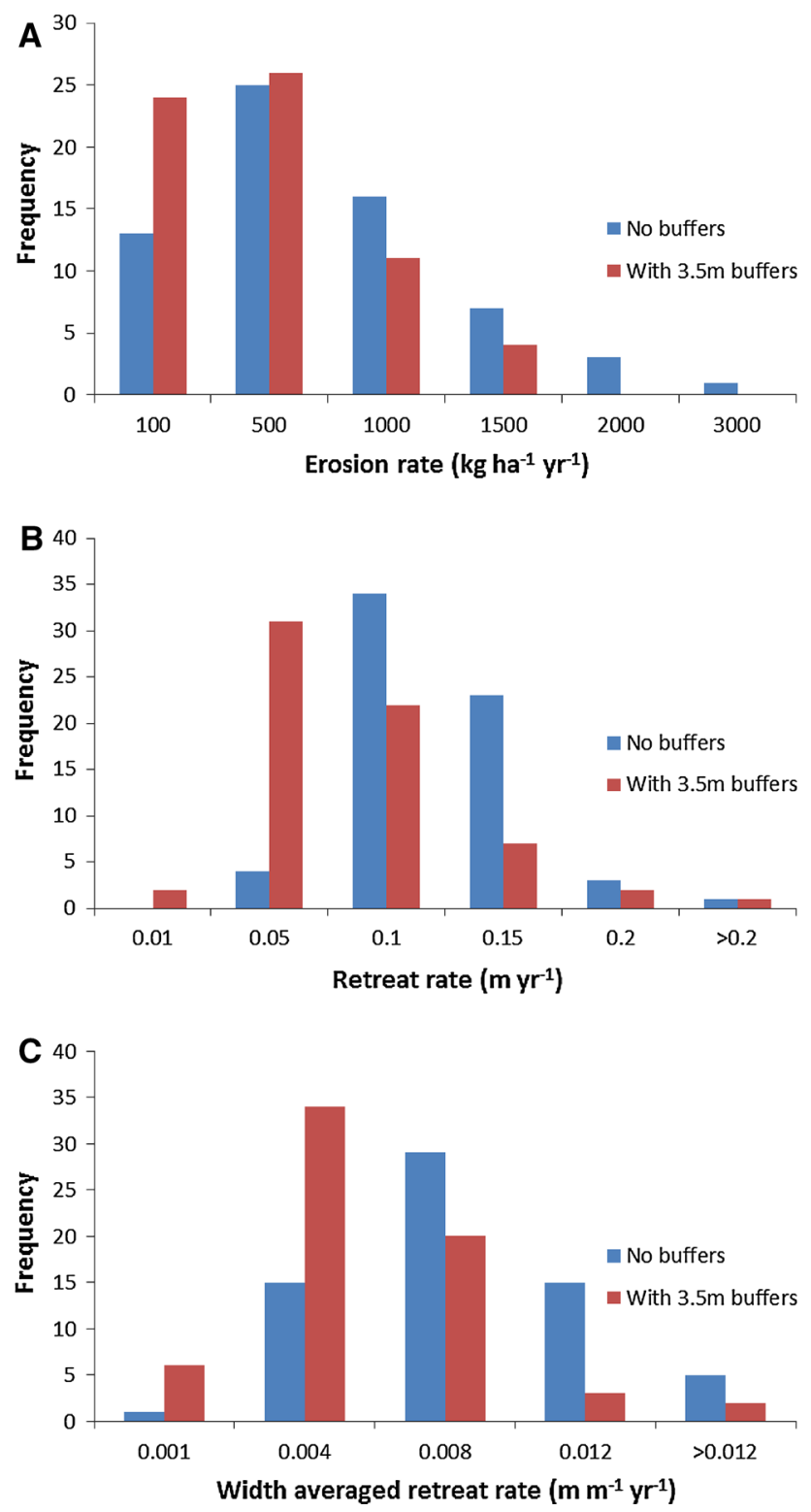

Fig. 3 Histograms showing the variability of channel bank erosion measured for all 65 WFD sub-catchments comprising the seven study catchments. Blue bars indicate upper estimate (no buffer used in overlay methodology) and red bars lower estimate (with $3.5 \mathrm{~m}$ buffer overlay methodology). a-erosion rates $\left(\mathrm{kg} \mathrm{ha}^{-1} \mathrm{yr}^{-1}\right)$, b-retreat rate $\left(\mathrm{m} \mathrm{yr}^{-1}\right), \mathbf{c}$-width-averaged retreat rate $\left(\mathrm{m} \mathrm{m}^{-1} \mathrm{yr}^{-1}\right)$

explain this influence. This data point was therefore removed prior to the final regression model presented here. Additionally, the variable sinuosity was found to not contribute significantly to either regression model ( $t$ statistic 1.739, $p=0.087)$. Sinuosity was therefore not included within the final regression model of width-averaged bank retreat rate presented here. The independent variables that were entered into the regression model for dependent variable width-averaged retreat rate $\left(\mathrm{m} \mathrm{m}^{-1} \mathrm{yr}^{-1}\right)$ without buffers were therefore upstream area, slope, and channel
Table 6 Upper and lower estimates of the annual mass of sediment released by bank erosion (tonnes per year) for each channel digitised within this study

\begin{tabular}{lll}
\hline Catchment & Channel & Annual bank erosion $\left(\mathrm{t} \mathrm{yr}^{-1}\right)$ \\
\hline Exe & Exe & $5874-67627$ \\
& Culm & $2905-42486$ \\
Avon & Creedy & $259-16955$ \\
& Avon & $6654-18301$ \\
& Bourne & $673-2702$ \\
& Ebble & $668-1945$ \\
Test and Itchen & Nadder & $2102-8876$ \\
& Wylye & $2402-7013$ \\
Stour & Test & $441-1763$ \\
& Itchen & $970-2811$ \\
& Stour & $2570-7505$ \\
& Little Stour & $536-1044$ \\
Wye & East Stour & $461-1632$ \\
& Sarre Penn & $54-510$ \\
& Wye & $25666-73340$ \\
Eye & Monnow & $1064-11032$ \\
Ouse & Lugg & $5949-13345$ \\
& Eye & $91-10239$ \\
& Ouse & $26614-68359$ \\
& Swale & $7393-61232$ \\
& Nidd & $977-19507$ \\
& Wharfe & $6088-19874$ \\
\hline
\end{tabular}

confinement version 3. The regression output is shown in Table 10. The absolute correlation and percentage of variance explained are 0.812 and $65.9 \%$, respectively. The $R^{2}$ and adjusted $R^{2}$ values indicated that the model generalises well (0.659 and 0.642, respectively) (Fig. 5).

The regression model produced the following predictive equation:

$$
\begin{aligned}
& \text { Width averaged retreat rate }=0.017 \\
& \quad+\left(0.001 \times \log _{10}(S+0.0001)\right)-\left(0.003 \times \log _{10} U A\right) \\
& \quad+\left(0.005 \times \log _{10} C C 3\right)
\end{aligned}
$$

where $S$ is the channel slope and $U A$ is the upstream area.

High residuals were classified as a standardised residual $<-2.58$ or $>2.58$ (Norusis 2005). The only residual was data point number 5 (River Bourne), which had the highest value of width-averaged retreat rate $\left(0.0138 \mathrm{~m} \mathrm{~m}^{-1} \mathrm{yr}^{-1}\right)$. Regression models often have less accuracy predicting high and low values which explains this elevated residual value. The low leverage value $(0.012)$ indicates this data point does not disproportionately influence the regression coefficients, and removal will not have a significant impact on regression coefficients $\left(R=0.837 R^{2}=0.701\right)$. Consequently, this data point was not removed on this basis. 
Table 7 Values of the mass of bank-eroded sediment reported by previous studies

\begin{tabular}{lll}
\hline Catchment & Mass of bank erosion $\left(\mathrm{t} \mathrm{yr}^{-1}\right)$ & Reference \\
\hline Exe & 1193 & Collins et al. (1997) \\
Culm & $3500+$ & Ashbridge (1995)* \\
Culm & 750 & Walling and Woodward (1995) \\
Culm & 900 & He and Owens (1995) \\
\hline
\end{tabular}

Studies marked with an asterisk used erosion pin methodologies and all others are based on sediment source fingerprinting. The percentages of sediment budgets within the Exe catchment from sediment fingerprinting studies are converted to a mass of bank erosion using values of annual suspended sediment load measured at the catchment outlet (Walling and Webb 1987; Walling and Bradley 1989)

Table 8 Correlations between all independent and dependent variables from all 65 sub-catchment

\begin{tabular}{|c|c|c|c|c|c|c|}
\hline & \multicolumn{3}{|l|}{ Without buffers } & \multicolumn{3}{|c|}{ With $3.5 \mathrm{~m}$ buffers } \\
\hline & $\begin{array}{l}\text { Erosion rate } \\
\left(\mathrm{kg} \mathrm{ha}^{-1} \mathrm{yr}^{-1}\right)\end{array}$ & $\begin{array}{l}\text { Retreat rate } \\
\left(\mathrm{m} \mathrm{yr}^{-1}\right)\end{array}$ & $\begin{array}{l}\text { Width-averaged retreat } \\
\text { rate }\left(\mathrm{m} \mathrm{m}^{-1} \mathrm{yr}^{-1}\right)\end{array}$ & $\begin{array}{l}\text { Erosion rate } \\
\left(\mathrm{kg} \mathrm{ha}^{-1} \mathrm{yr}^{-1}\right)\end{array}$ & $\begin{array}{l}\text { Retreat rate } \\
\left(\mathrm{m} \mathrm{yr}^{-1}\right)\end{array}$ & $\begin{array}{l}\text { Width-averaged retreat } \\
\text { rate }\left(\mathrm{m} \mathrm{m}^{-1} \mathrm{yr}^{-1}\right)\end{array}$ \\
\hline $\begin{array}{l}\text { Sinuosity } \\
\left(\log _{10}\right)\end{array}$ & -0.114 & 0.124 & $0.289^{*}$ & -0.039 & 0.217 & $0.346 * *$ \\
\hline Slope $\left(\log _{10}\right)$ & -0.054 & 0.052 & 0.219 & -0.124 & -0.129 & -0.013 \\
\hline $\begin{array}{l}\text { Upstream area } \\
\left(\log _{10}\right)\end{array}$ & $0.305^{*}$ & -0.029 & $-0.507 * *$ & 0.225 & -0.140 & $-0.430 * *$ \\
\hline $\mathrm{CC} 1\left(\log _{10}\right)$ & 0.069 & -0.030 & $0.532 * *$ & 0.120 & 0.111 & $0.437 * *$ \\
\hline CC2 $\left(\log _{10}\right)$ & 0.072 & -0.028 & $0.528 * *$ & 0.123 & 0.112 & $0.434 * *$ \\
\hline CC3 $\left(\log _{10}\right)$ & 0.031 & -0.045 & $0.572 * *$ & 0.084 & 0.104 & $0.464 * *$ \\
\hline
\end{tabular}

Statistically significant correlations are indicated by an asterisk; * at $95 \%$ level, and ** at $99 \%$ level

Table 9 Correlation matrix of all independent variables

\begin{tabular}{lllll}
\hline & Sinuosity $\left(\log _{10}\right)$ & Slope $\left(\log _{10}\right)$ & Upstream area $\left(\log _{10}\right)$ & CC2 $\left(\log _{10}\right)$ \\
\hline Slope $\left(\log _{10}\right)$ & 0.191 & & & CC3 $\left(\log _{10}\right)$ \\
Upstream area $\left(\log _{10}\right)$ & $-0.211^{*}$ & -0.179 & & \\
CC2 $\left(\log _{10}\right)$ & -0.022 & -0.102 & 0.066 & $0.997 * *$ \\
CC3 $\left(\log _{10}\right)$ & -0.005 & -0.082 & 0.014 & \\
\hline
\end{tabular}

Significant correlations are indicated with an asterisk; $*$ at $95 \%$ level, ** at $99 \%$ level. CC2 indicates channel confinement method $2, \mathrm{CC} 3$ indicates channel confinement method 3

With buffers applied, the initial regression analysis including all 65 data points indicated one high residual value (River Wye $=-2.67$, number 58 ). This data point also showed a high leverage value (0.097) and therefore had a disproportionate influence on regression coefficients. This point has the smallest value of width-averaged retreat rate $\left(0.00009 \mathrm{~m} \mathrm{~m}^{-1} \mathrm{yr}^{-1}\right)$ within the data set, which could partially explain this influence. This data point was therefore removed prior to the derivation of the final regression model. Additionally, the variable slope was found to not contribute significantly to the model and was therefore removed $(t$ statistic $=-1.046, p=0.300)$. The regression output is provided in Table 11. The absolute correlation and percentage of variance explained were 0.585 and $34.2 \%$, respectively (Fig. 6).

One residual, River Wye no. 55 (-2.91), was observed from the regression output. This data point had the lowest value of width-averaged retreat rate $\left(0.00018 \mathrm{~m} \mathrm{~m}^{-1} \mathrm{yr}^{-1}\right)$. This point did not have a disproportionate influence on the regression coefficients (leverage value 0.061 ) and therefore removal of this point did not have a significant impact on the regression coefficient $R$ and $R^{2}$ values ( 0.620 and 0.385 , respectively). On this basis, it was therefore retained in the final statistical model. 

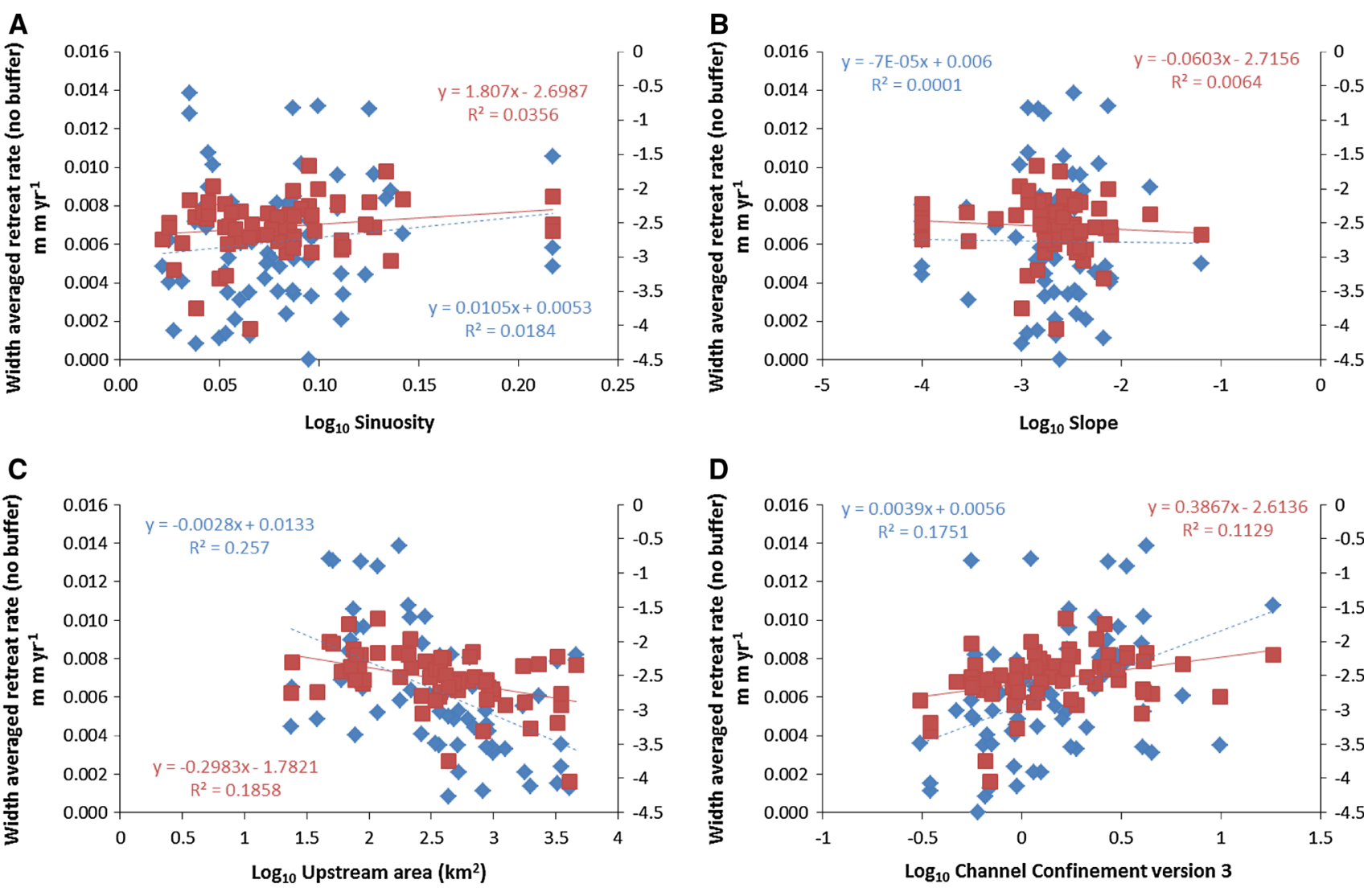

Fig. 4 Scatterplots illustrating the relationship between width-averaged retreat rate $\left(\mathrm{m} \mathrm{m}^{-1} \mathrm{yr}^{-1}\right)$ and (transformed) independent variables. Square data points and solid trendlines, regression equations, and $R^{2}$ values indicate values from overlay methodology without

buffers applied, and diamonds and dashed trendlines indicate data from the overlay methodology with $3.5 \mathrm{~m}$ buffers applied. asinuosity, b-slope, c-upstream area, d-channel confinement (version 3)

Table 10 Regression output statistics of the modeldependent variable widthaveraged retreat rate $\left(\mathrm{m} \mathrm{m}^{-1}\right.$ $\mathrm{yr}^{-1}$ ) without buffers applied to overlay methodology

\begin{tabular}{|c|c|c|c|c|c|c|c|}
\hline \multirow{2}{*}{$\frac{\mathrm{R}}{0.812}$} & $\mathrm{R}$ square & \multicolumn{2}{|c|}{ Adjusted R square } & \multicolumn{2}{|c|}{ Durbin-Watson } & ANOVA F & Sig. \\
\hline & 0.659 & 0.642 & & 1.624 & & 38.666 & 0.000 \\
\hline \multicolumn{2}{|c|}{ Variable } & $\mathrm{B}$ & Std. Error & Beta & $T$ & Sig. & Tolerance \\
\hline \multicolumn{2}{|c|}{ (Constant) } & 0.017 & 0.002 & & 10.229 & 0 & \\
\hline \multicolumn{2}{|c|}{$\log _{10}$ slope } & 0.005 & 0.001 & 0.232 & 3.061 & 0.003 & 0.989 \\
\hline \multicolumn{2}{|c|}{$\log _{10}$ Upstream area } & -0.003 & 0 & -0.508 & -6.711 & 0 & 0.99 \\
\hline \multicolumn{2}{|c|}{$\log _{10} \mathrm{CC} 3$} & 0.005 & 0.001 & 0.565 & 7.485 & 0 & 0.998 \\
\hline
\end{tabular}

\section{Discussion}

The results here have shown the potential for physical factors to be used as predictors of catchment scale bank erosion. Upstream catchment area showed a statistically significant correlation at the $99 \%$ level with channel bank erosion measured as a width-averaged retreat rate when measured using overlay methodologies with and without buffers $(R=-0.507$ and -0.430 , respectively). Additionally, when measured as a yield of sediment $\left(\mathrm{kg} \mathrm{ha}^{-1}\right.$ $\mathrm{yr}^{-1}$ ) without buffers, a significant correlation at the $95 \%$ level was observed with upstream catchment area (0.305). The sign of the relationship switches from positive to negative when measuring bank erosion as a width-averaged retreat rate, as opposed to a sediment yield, because dividing retreat rate by the width normalises the data. On this basis, the data from this study therefore suggest that bank erosion rates increase with upstream area. Hooke (1980) noted that bank erosion rate was related to catchment area, and this explained 53 and 39\% of variation in mean and maximum erosion rates, respectively. It is suggested that this is because catchment area represents a 
Fig. 5 Scatterplot of observed versus predicted values of width-averaged retreat rate $\left(\mathrm{m} \mathrm{m}^{-1} \mathrm{yr}^{-1}\right.$ ) without buffers applied and the regression line. The wider dashed lines represent the $95 \%$ prediction intervals, and curved dotted lines indicate $95 \%$ confidence intervals of predicted values
Table 11 Regression output statistics of the modeldependent variable widthaveraged retreat rate $\left(\mathrm{m} \mathrm{m}^{-1}\right.$ $\mathrm{yr}^{-1}$ ) with buffers applied to overlay methodology

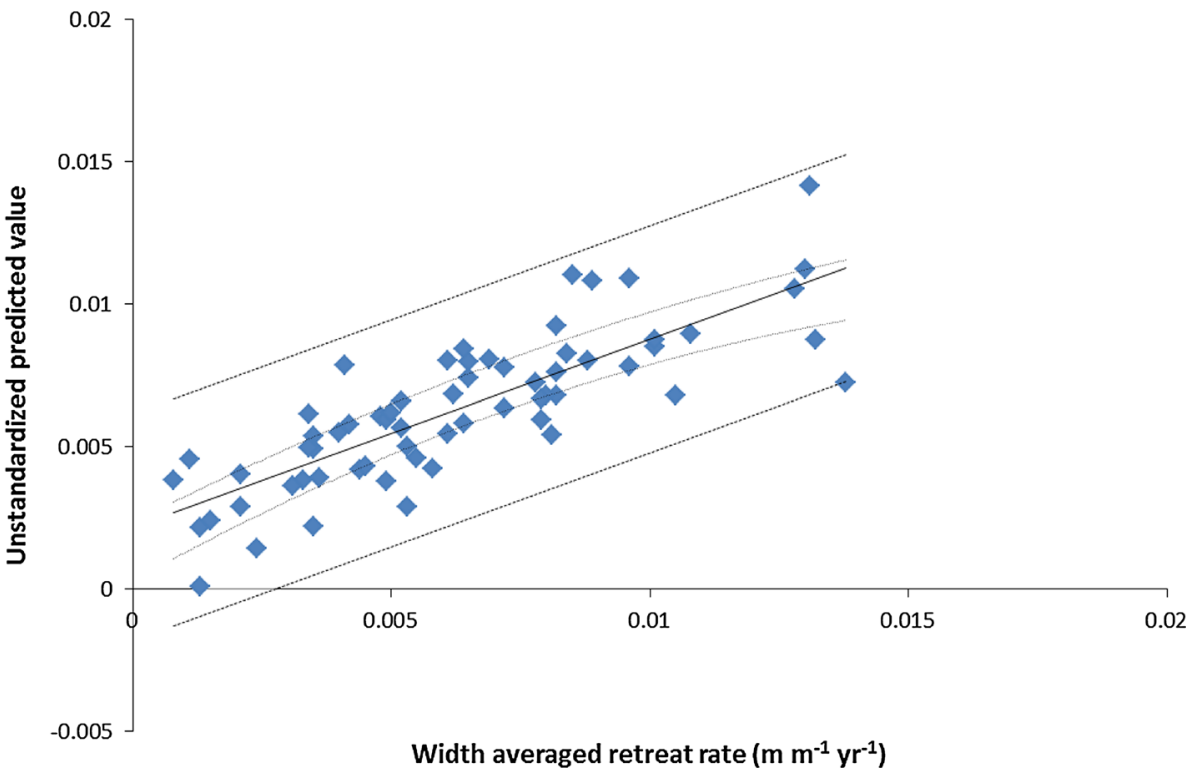

\begin{tabular}{|c|c|c|c|c|c|c|c|}
\hline \multirow{2}{*}{$\frac{\mathrm{R}}{0.637}$} & \multirow{2}{*}{$\frac{\text { R square }}{0.406}$} & \multicolumn{2}{|c|}{ Adjusted R square } & \multicolumn{2}{|c|}{ Durbin-Watson } & ANOVA F & Sig. \\
\hline & & 0.376 & & 1.271 & & 13.681 & 0.000 \\
\hline \multicolumn{2}{|c|}{ Variable } & B & Std. Error & Beta & $\mathrm{T}$ & Sig. & Tolerance \\
\hline \multicolumn{2}{|c|}{ (Constant) } & -2.204 & 0.192 & & -11.47 & 0 & \\
\hline \multicolumn{2}{|c|}{$\log _{10}$ Upstream area } & -0.227 & 0.064 & -0.361 & -3.565 & 0.001 & 0.994 \\
\hline \multicolumn{2}{|c|}{$\log _{10} \mathrm{CC} 3$} & 0.471 & 0.104 & 0.453 & 4.540 & 0 & 0.995 \\
\hline \multicolumn{2}{|c|}{$\log _{10}$ sinuosity } & 2.212 & 0.871 & 0.257 & 2.539 & 0.014 & 0.967 \\
\hline
\end{tabular}

Fig. 6 Scatter plot of observed versus predicted values of width-averaged retreat rate $\left(\mathrm{m} \mathrm{m}^{-1} \mathrm{yr}^{-1}\right)$ with buffers applied and the regression line. The wider dashed lines represent the $95 \%$ prediction intervals and curved dotted lines indicate $95 \%$ confidence intervals of predicted values

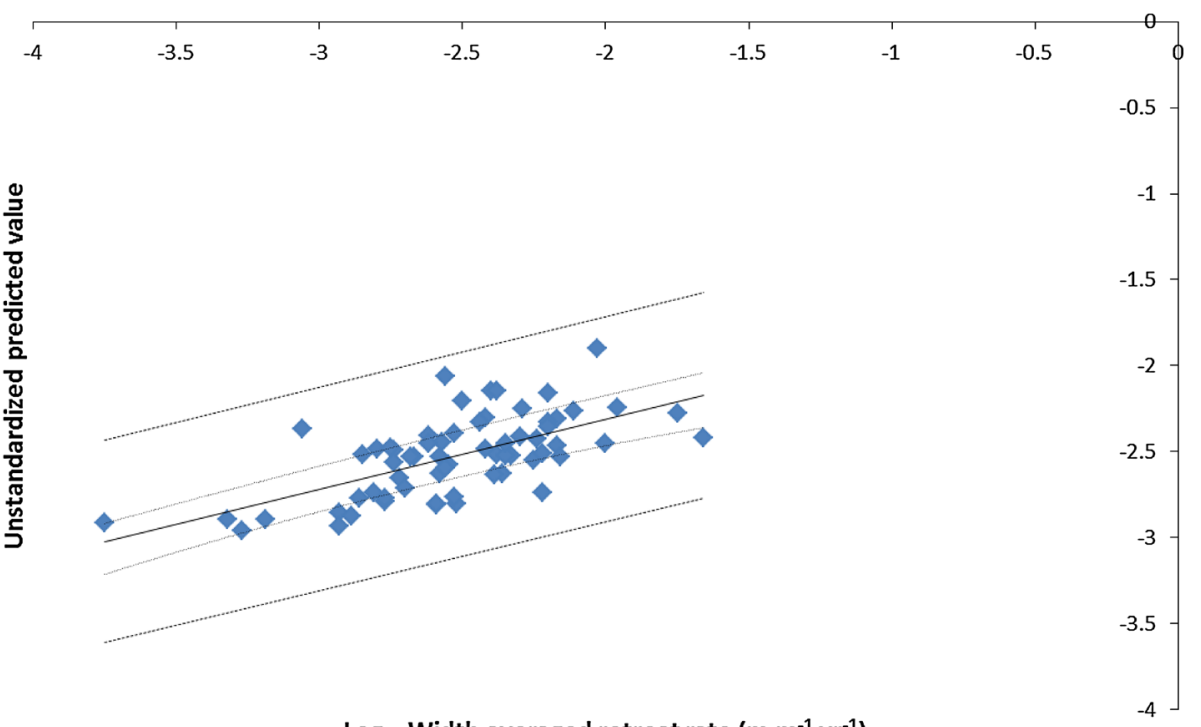

$\log _{10}$ Width averaged retreat rate $\left(\mathrm{m} \mathrm{m}^{-1} \mathrm{yr}^{-1}\right)$

channel banks increases, causing increased bank erosion (cf. the bank erosion index reported by Collins et al. 2009a, b). Furthermore, as bank height increases 
downstream, the shear stress acting on banks increases, increasing the risk of bank failure (Bull 1997; Micheli and Kirchner 2002; Walling et al. 2006) and the volume of sediment yield from bank erosion processes. However, Lawler et al. (1999) noted a nonlinear relationship between bank erosion and upstream area within the Swale-Ouse catchment and observed a peak in bank erosion rates in the middle reaches. The middle reaches (in their study) were surrounded by upland environments with a combination of peak stream power and erodible bank materials, hence the observed high flows. They also noted downstream sites were more consistently seasonally active. The nonlinear relationship that was observed in their study was based on 11 sites for 14-15 months. The lack of a nonlinear relationship observed within this study could be due to the considerable difference in timescale of the observations; in the Lawler et al. (1999) study, a large/sequence of events may dominate the observations with particular areas of the catchment being more sensitive to bank erosion than others. In the present study, the effects of localised sensitivity to individual events and within the catchment are not observed due to the longer temporal scale.

Width-averaged retreat rate $\left(\mathrm{m} \mathrm{m}^{-1} \mathrm{yr}^{-1}\right)$ showed a significant relationship with channel sinuosity at the 99 and 95\% level with without buffers applied, respectively. This relationship is positive. However, closer scrutiny of the scatterplot in Fig. 4a suggests that relationship between bank erosion and sinuosity may not be completely linear; bank erosion appears to increase with sinuosity up to a point (equivalent to a sinuosity of approximately 1.5). Channel sinuosity is inversely related to channel curvature ratio (the radius of channel curvature divided by the channel width) up to sinuosities of approximately 1.5. Further data analysis could be undertaken by splitting the data set to assess high and low curvature.

Channel confinement was measured as a ratio between floodplain or meander belt width and channel width. For each of the three methodologies used to estimate this potential control on river bank erosion, a decrease in channel confinement ratio represents an increase in confinement of the channel within the floodplain. Only a very weak positive relationship between channel bank erosion sediment yield $\left(\mathrm{kg} \mathrm{ha}^{-1} \mathrm{yr}^{-1}\right)$ and channel confinement was observed. However, none of these relationships were statistically significant; all $R$ values were $<0.2$ both with and without buffers used in the overlay methodology. The relationship between bank erosion and channel confinement measured as a width-averaged retreat rate $\left(\mathrm{m} \mathrm{m}^{-1}\right.$ $\mathrm{yr}^{-1}$ ) was statistically significant at the $99 \%$ level for all methods of channel confinement estimation, both with and without buffers applied in the overlay methodology. This positive relationship suggests that as channel confinement decreases (channel confinement ratio increases), the width- averaged retreat rate increases. Channels can migrate freely where they are unconfined by valley margins and therefore it follows that bank erosion/retreat rates will be higher in these scenarios compared with confined channels where lateral migration is restricted. It was noted that as this measure of bank erosion is calculated using channel width, as is channel confinement, this may lead to spurious correlations as a result of collinearity. Although no statistically significant correlations were observed between bank erosion measured as a retreat rate $\left(\mathrm{m} \mathrm{yr}^{-1}\right)$ and the channel confinement, a slight positive relationship (0.104-0.112) was observed between retreat rate and channel confinement with buffers applied (with no buffers correlations were extremely low; between -0.028 and -0.045$)$. This suggests that whilst some collinearity between these variables is inevitable, a positive relationship between width retreat rate and confinement ratio is genuine.

The level of channel confinement may indirectly influence bank erosion by influencing the sinuosity of the channel. Milne (1983) found that low sinuosity in channels was partly due to lateral confinement of the channel network by valley walls preventing free meander development. Additionally, Tooth et al. (2002) observed channel sinuosities of $\sim 1.1-1.3$ in areas confined by bedrock geology, and $\sim 1.75$ where channel migration was unrestricted. (Nicoll and Hickin 2010) observed that confined channels had a higher wavelength and curvature than unconfined rivers, with few channel cut-offs occurring. Unconfined and freely meandering rivers migrate by increasing bend amplitude, thereby decreasing channelbend radius and channel curvature ratio, and increasing sinuosity. Within confined channels, sinuosity, channel migration, and hence bank erosion are restricted. However, in this study no statistically significant relationship was observed between channel confinement and sinuosity (see Table 9). Reasons for this could include the small number of channels classified as confined within the study; according to the definition of confined by method 1 (Hall et al. 2007), only 8 of the 64 channels within this study are classed as confined. The relationship between confinement ratio and sinuosity may not be significant as the data set here is largely of unconfined and freely migrating channels, the sinuosity of which will be influenced by additional factors.

Slope did not show a statistically significant relationship with bank erosion measured as a sediment yield $\left(\mathrm{kg} \mathrm{ha}^{-1}\right.$ $\left.\mathrm{yr}^{-1}\right)$ or as a width-averaged retreat rate $\left(\mathrm{m} \mathrm{m}^{-1} \mathrm{yr}^{-1}\right)$ when considered individually. However, slope was included within the regression model of width-averaged retreat rate (without buffers) and in combination with upstream catchment area and channel confinement as independent variables was found to significantly contribute to the regression model (at the $95 \%$ level). Previous studies have 
noted the influence of slope on channel planform (Schumm and Khan 1972; Montgomery and Buffington 1997). Slope may indirectly influence bank erosion rates through the influence on channel planform, which may explain the lack of a significant correlation observed when considering slope individually as an independent variable. However, in this study, slope did not show a statistically significant relationship with sinuosity $(R=0.191)$.

Several additional factors known to influence bank erosion rates have not been considered within this analysis. These include vegetation, lithology and underlying geology, meteorological and climatic influences (e.g. freezethaw cycles), flow regimes, channel bank geometry, and anthropogenic influences (e.g. poaching by livestock accessing rivers for drinking water). Therefore, it is expected that the regression models would not completely explain the variance within the observed bank erosion data. For data points that the regression model predicts with a lower accuracy (those with high residual values), additional factors not considered within the regression are a likely source of error.

The GIS-based data collection and analysis methodology used within this study focuses on bank erosion resulting in lateral migration of channels yet excludes sediment generated through bank erosion processes that do not result in lateral migration. The importance of subaerial processes, such as freeze-thaw, has been observed, particularly in upper catchments during winter months (Lawler et al. 1999; Couper 2003). Fluvial entrainment and incision resulting in bank retreat at the waterline level of the bank has also been observed (Hooke 1979; Lawler et al. 1999). Where these forms of bank erosion are dominant, the GIS methodology used here may underestimate bankeroded sediment yield. These processes form the preliminary stages of bank erosion and lead to undermining and weakening of banks and later bank collapse, resulting in channel migration. Due to the long timescales over which bank erosion has been observed within this study, the errors due to omission of these processes are likely to be small.

The catchments selected for this study differ significantly in their geology and annual rainfall totals (see Table 1) and therefore have very different flow regimes and geomorphological histories. Differences in these local factors that have previously been observed to influence bank erosion rates (Henshaw et al. 2013) may also account for some of the scatter within the data that are observed in Figs. 5 and 6. For example, in study catchments with high permeability (such as the Test and Itchen), bank erosion rates are likely to be lower due to the dominance of weathering processes as an erosion mechanism (Test and Itchen annual retreat rate $<0.1 \mathrm{~m} \mathrm{yr}^{-1}$ ). Furthermore, many of the catchments within this study have a history of agricultural and flood management. Land use in has been noted in several previous studies to influence bank erosion rates through trampling and overgrazing by livestock (Kondolf et al. 2002), removal of vegetation (Michalková et al. 2011), and construction of flood protection measures (Winterbottom and Gilvear 2000; Michalková et al. 2011). The magnitude of influence of various land uses is individual to channel type; therefore, these localised factors have not been considered within the methodology developed here and may obscure any trends relating to the physical factors analysed. Additional analysis of the temporal variation of bank erosion using the data set could also prove interesting.

The correlation and regression coefficients when bank erosion rate is calculated as a width-averaged retreat rate are higher than when bank erosion is calculated as a sediment yield. This is likely to be due to the error introduced to the calculation of bank erosion when calculating sediment volumes using estimates of bank height and sediment density. The RHS data used for bank height estimation included a total of 180 channel survey points across the 65 WFD sub-catchments for which bank erosion rates were estimated. However, channel bank heights are likely to be highly spatially variable, so estimates based on only one bank height per sub-catchment will introduce an error when estimating sediment mass released by bank erosion. Additionally, the bank heights within the RHS data have been recorded over a short time period (a few years). Channel bank heights are also temporally variable, particularly in areas of active channel bank erosion; therefore, whilst bank height may be representative for the digitisation period 2010, it is not possible to assess the accuracy of bank height data across the catchments for the previous digitised time periods. As the digitising covers up to 150 years, estimation of one bank height for all time periods will introduce an error within the calculation of bank erosion sediment yield. Any comparison of estimates of sediment erosion masses generated by this study with those reported by previous work (Table 7) should also bear in mind the temporal inconsistencies of the data sets since the latter were generally based on short-term studies using sediment fingerprinting or erosion pins.

Previous studies have observed annual channel bank retreat rates within the Exe catchment of $0.18-0.28 \mathrm{~m} \mathrm{yr}^{-1}$ (Hooke 1980; Ashbridge 1995) and within the Ouse catchment of 0.067-0.377 $\mathrm{m} \mathrm{yr}^{-1}$ (Lawler et al. 1999). These are broadly comparable to the average annual retreat rates estimated within this study; Exe: $0.014-0.163 \mathrm{~m} \mathrm{yr}^{-1}$, Ouse: $0.026-0.229 \mathrm{~m} \mathrm{yr}^{-1}$ (lower and upper estimates from methodologies with and without buffers, respectively). Literature values from previous studies cited here were from particularly dynamic reaches (Swale, Ouse catchment, and Culm, Exe catchment) which could explain the slightly lower bank retreat rates observed within this study. Table 7 
presents estimates of the annual mass of bank-eroded sediment reported by previous studies from the study catchments, using sediment fingerprinting and erosion pin methodologies. The values obtained from this study are of similar magnitudes to these previous published estimates; however, the significant methodological differences between this study and literature values should be noted (both temporal and scale differences).

The total mass of sediment generated through bank erosion processes annually within this study showed a large range of uncertainty. It is important to note that these values represent the total mass of sediment generated through bank erosion. A proportion of bank-derived sediment will be deposited either within the channel, or during overbank floodplain sedimentation. Therefore, when compared to estimates of net sediment loss from bank erosion from studies using techniques such as sediment fingerprinting coupled with suspended sediment yields and statistical modelling (e.g. Collins and Anthony 2008; Collins et al. 2009a, b, 2010) which focus on the clay- and siltsized fractions only, excluding sand-sized material, the values presented in this paper can be expected to be considerably higher. This study does not consider bank toe deposition, again emphasising that the values reported herein represent the gross rather than net release of bankeroded sediment. Finally, the analysis herein does not consider the impact of channel margin protection or engineering works in reducing the bank erosion in specific reaches. Previous strategic predictive models for England and Wales have also generated bank sediment loss estimates without such corrections (e.g. Collins and Anthony 2008; Collins et al. 2009a, b). Comparison of bank erosion estimates within the Ouse catchment generated by this study with annual suspended sediment load estimates presented in Walling et al. 1999 indicates the estimate of bank erosion contribution to the sediment budget as between 35 and $91 \%$. This range in bank contribution is higher than expected due to the total bank-eroded sediment being compared with suspended sediment load at the catchment outlet; some bank-eroded sediment will be deposited elsewhere and will contain bedload sediments. The contrasting time periods covered by the estimates used in this comparison should also be considered.

\section{Conclusions}

The channel bank erosion rates estimated by this study from GIS data suggest that river bank erosion generates a significant mass (representing gross sediment loss) of sediment in several contrasting catchments across England and Wales. Additionally, the variability of observed bank erosion rates both within and between catchments has been highlighted. Channel bank erosion rates vary both spatially and temporally due to the numerous factors which influence bank retreat, and these factors are likely characterised by complex interactions.

The statistical analysis performed by this study indicates a significant correlation between upstream area, channel confinement, sinuosity, and channel bank erosion when calculated as a width-averaged retreat rate $\left(\mathrm{m} \mathrm{m}^{-1} \mathrm{yr}^{-1}\right)$. The analysis therefore suggests that these variables are useful predictors of bank erosion. The regression model of width-averaged retreat rate (without buffers) showed the highest predictive accuracy, and this equation could be used to estimate bank erosion rates within catchments across England and Wales that share similar characteristics to the basins examined here. Further investigation of the relationships including variables influenced by climate zone or projected change would be beneficial. Sediment generation can be heavily influenced by gradients in rainfall and run-off responses across climate zones, as illustrated nationally for bank erosion across England and Wales by Collins and Anthony (2008) and Collins et al. (2009a, b). Sediment mobilisation is forecast to change with future climate scenarios, and this change is likely to impact on bank erosion as well as other sediment generation processes and sources.

The methodology used within this study has enabled spatial coverage of data that are considerable in comparison with similar previous studies (Hooke 1980, 2008; Gurnell et al. 1994; Lawler et al. 1997) and therefore the findings from this study build upon the existing literature. The identification of key factors influencing bank erosion and their relative significance can therefore be used to identify catchments at risk of significant channel bank erosion as a result of physical factors, and to inform future bank erosion model development. The need to consider bank erosion as a potentially important sediment source is critical for the development of catchment sediment budget models which can be used for scenario analysis to inform improved management of sediment-related problems impacting on water quality and ecological status.

Acknowledgements Thanks are extended to Cranfield University and the Environment Agency for provision of data sets. The studentship during which this work was undertaken was co-funded by ALC using ADAS central funding, and the University of Exeter, UK.

Open Access This article is distributed under the terms of the Creative Commons Attribution 4.0 International License (http://crea tivecommons.org/licenses/by/4.0/), which permits unrestricted use, distribution, and reproduction in any medium, provided you give appropriate credit to the original author(s) and the source, provide a link to the Creative Commons license, and indicate if changes were made. 


\section{References}

Abam T (1993) Factors affecting distribution of instability of river banks in the Niger delta. Eng Geol 35:123-133

Allan D, Erickson D, Fay J (1997) The influence of catchment land use on stream integrity across multiple spatial scales. Freshw Biol 37:149-161

Ashbridge D (1995) Processes of river bank erosion and their contribution to the suspended sediment load of the River Culm, Devon. In: Foster I, Gurnell A, Webb B (eds) Sediment and water quality in river catchments. Wiley, Chichester, pp 229-245

Bathurst JC, Thorne CR, Hey RD (1977) Direct measurements of secondary currents in river bends. Nature 269:504-506

Berry DA (1987) Logarithmic transformations in ANOVA. Biometrics 43:439-456

Biswas and Pani (2015) Estimation of soil erosion using RUSLE and GIS techniques: a case study of Barakar River basin, Jharkhand, India. Model Earth Syst Environ 1:42

Bull LJ (1997) Magnitude and variation in the contribution of bank erosion to the suspended sediment load of the River Severn, UK. Earth Surf Process Landf 22:1109-1123

Collins AL, Anthony SG (2008) Assessing the likelihood of catchments across England and Wales meeting 'good ecological status' due to sediment contributions from agricultural sources. Environ Sci Policy 11:163-170

Collins AL, Walling DE (2004) Documenting catchment suspended sediment sources: problems, approaches and prospects. Prog Phys Geogr 28:159-196

Collins A, Walling D, Leeks G (1997) Fingerprinting the origin of fluvial suspended sediment in larger river basins: combining assessment of spatial provenance and source type. Geogr Anna Ser A Phys Geogr 79:239-254

Collins AL, Anthony SG, Hawley J, Turner T (2009a) The potential impact of projected change in farming by 2015 on the importance of the agricultural sector as a sediment source in England and Wales. Catena 79:243-250

Collins AL, Anthony SG, Hawley J, Turner T (2009b) Predicting potential change in agricultural sediment inputs to rivers across England and Wales by 2015. Mar Freshw Res 60:626-637

Collins AL, Walling DE, Webb L, King P (2010) Apportioning catchment scale sediment sources using a modified composite fingerprinting technique incorporating property weightings and prior information. Geoderma 155:249-261

Collins AL, Naden PS, Sear DA, Jones JI, Foster IDL, Morrow K (2011) Sediment targets for informing river catchment management: international experience and prospects. Hydrol Process 25:2112-2129

Collins AL, Zhang Y, Walling DE, Grenfell SE, Smith P, Grischeff J, Locke A, Sweetapple A, Brogden D (2012) Quantifying finegrained sediment sources in the River Axe catchment, Southwest England: application of a Monte Carlo numerical modelling framework incorporating local and genetic algorithm optimisation. Hydrol Process 26:1962-1983

Collins AL, Zhang YS, Duethmann D, Walling DE, Black KS (2013) Using a novel tracing-tracking framework to source fine-grained sediment loss to watercourses at sub-catchment scale. Hydrol Process 27:959-974

Couper P (2003) Effects of silt-clay content on the susceptibility of river banks to subaerial erosion. Geomorphology 56:95-108

Couper P, Stott TIM, Maddock IAN (2002) Insights into river bank erosion processes derived from analysis of negative erosion-pin recordings: observations from three recent UK studies. Earth Surf Process Landf 79:59-79

De Rose RC, Basher LR (2011) Measurement of river bank and cliff erosion from sequential LIDAR and historical aerial photography. Geomorphology 126:132-147
De Rose RC, Wilson DJ, Bartley R, Wilkinson SN (2005) Riverbank erosion and its importance to uncertainties in large scale sediment budgets. In: Walling DE, Horowitz JA (eds) Proceedings of the international symposium on sediment budgets (S1) held during the seventh scientific assembly of the IAHS at Foz do Iguacu, Brazil, 3-9 April 2005, Sediment Budgets 1, IAHS Publ., vol. 291, IAHS Press pp 85-92

Devlin MJ, Barry J, Mills DK, Gowen RJ, Foden J, Sivyer D, Tett P (2008) Relationships between suspended particulate material, light attenuation and Secchi depth in UK marine waters. Estuar Coast Shelf Sci 79:429-439

Downward SR, Gurnell AM, Brookes A (1994) A methodology for quantifying river channel planform using GIS. IAHS Publ. no 224

Environment Agency (2008) River habitat survey

Gautier E, Brunstein D, Vauchel P, Roulet M, Fuertes O, Guyot J, Darozzes J, Bourrel L (2007) Temporal relations between meander deformation, water discharge and sediment fluxes in the floodplain of the Rio Beni (Bolivian Amazonia). Earth Surf Process Landf 32:230-248

Gurnell A, Downward SR, Jones R (1994) Channel planform change on the river Dee meanders, 1876-1992. Regul Rivers Res Manag 9:187-204

Hall JE, Holzer DM, Beechie TJ (2007) Predicting river floodplain and lateral channel migration for salmon habitat conservation. J Am Water Resour Assoc 43:786-797

He Q, Owens P (1995) Determination of suspended sediment provenance using caesium-137, unsupported lead-210 and radium-226: a numerical 388 mixing model approach. In: Foster I, Gurnell A, Webb B (eds) Sediment and water quality in river catchments. Wiley, Chichester

Henshaw AJ, Thorne CR, Clifford NJ (2013) Identifying causes and controls of river bank erosion in a British upland catchment. Catena 100:107-119

Hessel R, van Asch T (2003) Modelling gully erosion for a small catchment on the Chinese Loess Plateau. Catena 54:131-146

Hey RD, Thorne CR (1975) Secondary flow in river channels. Area 7(3):191-195

Hickin E, Nanson G (1975) The character of channel migration on the Beatton River, Northeast British. Geol Soc Am Bull 86:487-494

Hooke JM (1979) An analysis of the processes of river bank erosion. J Hydrol 42:39-62

Hooke J (1980) Magnitude and distribution of rate of river bank erosion. Earth Surf Process 5:143-157

Hooke J (2003) Coarse sediment connectivity in river channel systems: a conceptual framework and methodology. Geomorphology 56:79-94

Hooke JM (2008) Temporal variations in fluvial processes on an active meandering river over a 20 -year period. Geomorphology 100:3-13

Hughes M, McDowell PF, Marcus WA (2006) Accuracy assessment of georectified aerial photographs: implications for measuring later channel movement in GIS. Geomorphology 74:1-16

Janes VJ (2013) An analysis of channel bank erosion and development of a catchment sediment budget model, Unpublished thesis, University of Exeter. Available: http://hdl.handle.net/10871/14870

Julian J, Torres R (2006) Hydraulic erosion of cohesive riverbanks. Geomorphology 76:193-206

Julien PY (2002) River mechanic. Cambridge University Press, Cambridge

Knighton AD (1973) Riverbank erosion in relation to streamflow conditions, river Bollin-Dean, Cheshire. East Midland Geogr 5:416-426

Knighton D (1998) Fluvial forms and processes: a new Perspective. Routledge, Oxford UK 
Kondolf G, Piégay H, Landon N (2002) Channel response to increased and decreased bedload supply from land use change: contrasts between two catchments. Geomorphology 45:35-51

Kronvang B, Andersen HE, Larsen SE, Audet J (2013) Importance of bank erosion for sediment input, storages and export at the catchment scale'. J Soils Sediment 13:230-241

Land IS (2014) Soils Data (c) Cranfield University (NSRI) and for the Controller of HMSO

Laubel A, Kronvang B, Hald AB, Jensen C (2003) Hydromorphological and biological factors influencing sediment and phosphorus loss via bank erosion in small lowland rural streams in Denmark. Hydrol Process 17:3443-3463

Lawler DM (1991) A new technique for the automatic monitoring of erosion and deposition rates. Water Resour Res 27:2125-2128

Lawler DM (1993) Needle ice processes and sediment mobilization on river banks: the river Ilston, West Glamorgan, UK. J Hydrol 150:81-114

Lawler DM, Couperthwaite J, Bull LJ, Harris NM (1997) Bank erosion events and processes in the upper severn basin. Hydrol Earth Syst Sci 1:523-534

Lawler DM, Grove JR, Couperthwaite JS, Leeks GL (1999) Downstream change in river bank erosion rates in the Swale and Ouse system, northern England. Hydrol Process 13:977-992

Lewin G, Brindle B (1977) Confined meanders. In: Gregory K (ed) River channel changes. Wiley, Hoboken, pp 221-233

Leys KF, Werritty A (1999) River channel planform change: software for historical analysis. Geomorphology 29:107-120

Lu D, Li G, Calladares GS, Batistella M (2004) Mapping soil erosion risk in Rondônia, Brazilian Amazonia: using RUSLE, remote sensing and GIS. Land Degredation Dev 15:499-512

Lu S, Kronvang B, Audet J, Trolle D, Andersen HE, Thodsen H, van Griensven A (2015) Modelling sediment and total phosphorus export from a lowland catchment: comparing sediment routing methods. Hydrol Process 29:280-294

Mackey SD, Bridge JS (1992) A revised FORTRAN program to simulate alluvial stratigraphy. Comput Geosci 18:119-181

Mattia C, Bischetti G, Gentile F (2005) Biotechnical characteristics of root systems of typical Mediterranean species. Plant Soil 278:23-32

Michalková M, Piégay H, Kondolf GM, Greco SE (2011) Lateral erosion of the Sacramento River, California (1942-1999), and responses of channel and floodplain lake to human influences. Earth Surf Process Landf 36:257-272

Micheli E, Kirchner J (2002) Effects of wet meadow riparian vegetation on streambank erosion. 1. Remote sensing measurements of streambank migration and erodibility. Earth Surf Process Landf 27:627-639

Milne J (1983) Patterns of confinement in some stream channels of upland Britain. Geogr Ann Ser A Phys Geogr 65:67-83

Montgomery DR, Buffington JM (1997) Channel-reach morphology in mountain drainage basins. Geol Soc Am Bull 109:596-611

Neal CWM, Andera AM (2015) Suspended sediment supply dominated by bank erosion in a low-gradient agricultural watershed, Wildcat Slough, Fisher, Illinois, United States. J Soil Water Conserv 70:145-155

Neller R (1988) A comparison of channel erosion in small urban and rural catchments, Armidale, New South Wales. Earth Surf Process Landf 13:1-7

Nicoll TJ, Hickin EJ (2010) Planform geometry and channel migration of confined meandering rivers on the Canadian prairies. Geomorphology 116:37-47

Norusis M (2005) SPSS 13.0 guide to data analysis. Prentice Hall, New Jersey
Owens PN, Walling DE, Leeks GJL (2000) Tracing fluvial suspended sediment sources in the catchment of the River Tweed, Scotland using composite fingerprints and a numerical mixing model. In: Foster ID (ed) Tracers in Geomorphology. Wiley, Chichester, pp 291-308

Rapp C, Abbe T (2003) A framework for delineating channel migration zones. Ecology Publication

Rhoades EL, O'Neal MA, Pizzuoto JE (2009) Quantifying bank erosion on the South River from 1937 to 2005 and its importance in assessing $\mathrm{Hg}$ contamination. Appl Geogr 29:125-134

Schilling K, Wolter C (1999) Detailed GPS survey of Walnut Creek, Iowa: channel characteristics and spatial relationships [WWW Document]. Iowa Geological and Water Survey. URL http:// www.igsb.uiowa.edu/Mapping/WaterQualityAg/walnut/wntpost/ wntpost.htm. Accessed 26 Nov 13

Schumm S, Khan H (1972) Experimental study of channel patterns. Geol Soc Am Bull 83:1755-1770

Simon A, Collison A (2002) Quantifying the mechanical and hydrologic effects of riparian vegetation on streambank stability. Earth Surf Process Landf 27:527-546

Soulsby C, Youngson A, Moir H, Malcolm IA (2001) Fine sediment influence on salmonid spawning habitat in a lowland agricultural stream: a preliminary assessment. Sci Total Environ 265:295-307

Theurer F, Harrod TR, Theurer M (1998) Sedimentation and Salmonids in England and Wales. Environment Agency R\&D technical report P194, Swindon

Thorne C (1991) Bank erosion and meander migration of the Red and Mississippi rivers, USA. IAHS PUBL WALLINGFORD,(ENGL). pp 301-313

Tooth S, McCarthy TS, Brandt D, Hancox PJ, Morris R (2002) Geological controls on the formation of alluvial meanders and floodplain wetlands: the example of the Klip River, eastern Free State, South Africa. Earth Surf Process Landf 27:797-815

Vente J, Poesen J, Verstraeten G, Van Rompaey A, Govers G (2008) Spatially distributed modelling of soil erosion and sediment yield at regional scales in Spain. Global Planet Change 60:393-415

Walling DE (2005) Tracing suspended sediment sources in catchments and river systems. Sci Total Environ 344:159-184

Walling DE, Bradley SB (1989) Rates and patterns of contemporary floodplain sedimentation: a case study of the river Culm, Devon, UK. GeoJournal 19:53-62

Walling DE, Collins AL (2005) Suspended sediment sources in British rivers. In: Sediment Budgets 1 International Association of Hydrological Sciences Publication No. 291, Wallingford, pp 123-133

Walling DE, Webb BW (1987) Suspended load in gravel-bed rivers: UK experience. In: Thorne CR, Bathurst JC, Hey RD (eds) Gravel-bed rivers. Wiley, Hoboken, pp 291-732

Walling DE, Woodward J (1995) Tracing sources of suspended sediment in river basins: a case study of the River Culm, Devon, UK. Mar Freshw Res 46:327-336

Walling DE, Owens PPN, Leeks GJLG (1999) Fingerprinting suspended sediment sources in the catchment of the River Ouse, Yorkshire, UK. Hydrol Process 975:955-975

Walling DE, Collins AL, Jones PA, Leeks GJL, Old G (2006) Establishing fine-grained sediment budgets for the Pang and Lambourn LOCAR catchments, UK. J Hydrol 330:126-141

Walling DE, Collins AL, Stroud RW (2008) Tracing suspended sediment and particulate phosphorus sources in catchments. J Hydrol 350:274-289

Wilkinson SN, Olley JM, Prosser IP, Read AM (2005) Targeting erosion control in large river systems using spatially distributed 
sediment budgets, Geomorphological Processes and Human Impacts in River Basins. International Association of Hydrological Sciences Publication No. 299IAHS Press, Wallingford, UK, pp 56-64

Williams G (1986) River meanders and channel size. J Hydrol $88: 147-164$
Winterbottom SJ, Gilvear DJ (2000) A GIS-based approach to mapping probabilities of river bank erosion: regulated river Tummel, Scotland. Regul Rivers Res Manag 16:127-140

Yamamura K (1999) Transformation using $(x+0.5)$ to stabilize the variance of populations. Res Popul Ecol 41:229-234 